\title{
Trends and patterns of marijuana use in men and women seeking drug treatment
}

\author{
David Bruno Díaz-Negrete, ${ }^{1}$ Solveig E. Rodríguez-Kuri, ${ }^{2}$ Alma Delia Gutiérrez-Lopez, ${ }^{3}$ \\ Ricardo Sánchez-Huesca, ${ }^{4}$ Carmen Fernández-Cáceres ${ }^{5}$
}

1 Dirección de Investigación y Enseñanza, Centros de Integración Juvenil

2 Departamento de Investigación Clínica y Epidemiológica, Centros de Integración Juvenil.

${ }^{3}$ Departamento de Investigación Psicosocial, Centros de Integración Juvenil.

${ }^{4}$ Dirección General Adjunta Normativa, Centros de Integración Juvenil.

${ }^{5}$ Dirección General, Centros de Integración Juvenil.

Correspondence:

David Bruno Díaz Negrete.

Dirección de Investigación y Enseñanza, Centros de Integración Juvenil, A.C.

Tlaxcala 208, Col. Hipódromo, Del. Cuauhtémoc, C.P. 06100, Ciudad de México, México

Phone: +52 (55) 5999-4949, ext. 7740.

Email: dir.invens@cij.gob.mx, cijinvestigacion@yahoo.com.mx

Received first version: April 7, 2017 Second version: May 9, 2017 Accepted: May 24, 2017

doi:10.17711/SM.0185-3325.2017.013

\begin{abstract}
Introduction. Marijuana is the world's most widely used illegal drug. In Mexico, it is the drug of choice for both male and female users of all ages, and there has been a recent increase in its use. Objective. To describe drug use trends in people seeking treatment by sex and age range, and to explore different patterns. Method. To provide a description of trends and rates of increase for the population attended between 2005 and 2016 and to make a comparative analysis of patterns of use in a sample of 11595 marijuana users who received treatment in 2016. Results. In general, there has been a greater increase in use in the group ages twelve to seventeen. The greatest increase in lifetime use was reported among women in this age range. The greatest increase in marijuana use in the past month was found among women aged eighteen to thirty-five. Women use a greater variety of substances, and a higher number of younger women report using cocaine, methamphetamines, benzodiazepines and hallucinogens than men. Discussion and conclusion. Significant increases in marijuana use have been registered among girls under 18 and women in recent years. The differences in trends and patterns of use for men and women are being reduced and reconfigured.
\end{abstract}

Keywords: Marijuana abuse, male, female, trends, patterns of substance abuse.

\section{RESUMEN}

Introducción. La mariguana es la droga de mayor consumo en el mundo. En México, es la droga preferida por ambos sexos y en todos los grupos de edad, y en su consumo ha habido un incremento desde hace varios años. Objetivo. Describir las tendencias del uso de mariguana en solicitantes de tratamiento, por sexo y rango de edad, y explorar diferencias en el patrón de consumo, según sexo. Método. Se describieron tendencias y tasas de crecimiento en población atendida entre 2005 y 2016 y se realizó un análisis comparativo del patrón de consumo con una muestra de 11595 usuarios de mariguana recibidos para tratamiento en 2016. Resultados. En general, se registran mayores tasas de crecimiento en el grupo de 12 a 17 años. El mayor incremento del uso alguna vez en la vida corresponde a las mujeres de este rango; el del uso en el último mes y como droga de mayor impacto, a las de 18 a 35 años. Las mujeres consumen un mayor número de sustancias. Las de menor edad refieren el uso de cocaína, metanfetaminas, éxtasis, benzodiacepinas y alucinógenos en mayor proporción que los hombres. Discusión y conclusión. Los menores de edad y las mujeres tienen un mayor peso en el aumento del uso de mariguana registrado en los últimos años. Las diferencias en las tendencias y el patrón de consumo entre sexos se están reduciendo y reconfigurando.

Palabras clave: Abuso de mariguana, hombres, mujeres, tendencias, patrón de consumo. 


\section{INTRODUCTION}

Marijuana is the world's most widely used drug. According to estimates, in 2014, 183 million people between the ages of twelve and sixty-four years had used marijuana in the previous twelve months, equivalent to $3.8 \%$ of the population, with a rate of use in the North American region of 12.1\% (United Nations Office on Drugs and Crime, 2016).

According to the National Addictions Survey for Mexico, cannabis is the drug of choice for both sexes across all age groups (Linares, Cravioto, García \& Medina-Mora, 2002). In 2011 , a $6.0 \%$ prevalence of lifetime use was reported, nearly two percentage points above the 2008 rate (Secretaría de Salud (SSA [Ministry of Health]), Consejo Nacional contra las Adicciones (CONADIC [National Council against Drugs]), Instituto Nacional de Psiquiatría Ramón de la Fuente Muñiz (INPRFM [National Institute of Psychiatry]), Instituto Nacional de Salud Pública (INSP [National Institute of Public Health]), 2011) with higher percentages of use in Mexico City (6.7\%) and the northwest and northeast regions ( $7.4 \%$ in both cases).

Increased marijuana use is also observed in the lifetime use category for three age groups. Use in the population aged twelve to seventeen saw an increase from $1.1 \%$ in 2002 to $2.4 \%$ in 2011 ; in the group aged eighteen to thirty-four, it rose from $4.6 \%$ to $8.7 \%$ (and to $15 \%$ for men), whereas in the group aged thirty-five to sixty-five, it increased from $3.5 \%$ to $4.5 \%$ during the same period (SSA, CONADIC, INPRFM, INSP, 2011).

A survey of students conducted in 2014 yielded a 2.3\% prevalence of lifetime marijuana use for fifth and sixth graders, and a $10.6 \%$ prevalence for middle and high school students (compared with $1.5 \%$ in 1991) $-12.9 \%$ in the case of boys and $8.4 \%$ in the case of girls-; and up to $18.1 \%$ in high school students (INPRFM, CONADIC, SSA, 2015).

Among male middle and high school students in Mexico City, lifetime marijuana use rose from $4.5 \%$ in 1991 to $22.0 \%$ in 2014. During that same period, use among female students increased from $1.1 \%$ to $17.2 \%$ (Villatoro, Oliva, Mujica, Fregoso, Bustos \& Medina-Mora, 2015).

The differences in drug use for men and women have been reduced over time, according to the Encuesta Nacional de Adicciones [National Addiction Survey] (SSA, CONADIC, INPRFM, INSP, 2011). The Sistema de Reporte de Información en Drogas [Drug Information Report System] (Ortíz, Soriano, Meza, Martínez \& Galván, 2006) reported that $70.7 \%$ of men identified at law enforcement, social welfare and public health institutions (including detoxification centers, drug treatment centers, psychiatric care centers and twenty six Centros de Integración Juvenil (CIJs) [Youth Integration Centers]) in the Mexico City metropolitan area, between 1999 and 2004 had used marijuana at least once in their lifetime, as opposed to $65.8 \%$ of women. Likewise, trends registered among middle and high school students in
Mexico City point to a greater similarity in drug use in general, particularly marijuana use, among boys and girls (Villatoro, Oliva, Mujica, Fregoso, Bustos \& Medina-Mora, 2015).

Despite similar cannabis use trends in men and women, it has been found that men are more likely to seek treatment for problems associated with marijuana use, while women tend to seek treatment for use of opiates, sedatives and hypnotics (Castillo \& Gutiérrez, 2008). Likewise, the Sistema Epidemiológico y Estadístico de Defunciones (SEED [Epidemiological and Statistical System for Deaths]) recorded 5.7 male deaths for every female death attributed to drugs (Kuri, Álvarez, Cravioto, García, Galván \& Tapia, 2002).

With this background, this study seeks to describe the marijuana use trends registered in those seeking treatment at the CIJs between 2005 and 2016, by sex and age range. A second goal is to explore the similarities and differences in patterns of use reported by male and female marijuana users seeking treatment in 2016, grouped into two age ranges.

\section{METHOD}

This study is based on information provided by illegal drug users seeking treatment at CIJs, a Mexican organization specializing in prevention, treatment and research on drug, alcohol and tobacco use and abuse. It has 117 treatment centers distributed throughout the thirty-two states in Mexico, providing treatment to the general public.

The first part of this study includes data on marijuana use trends in drug users seeking treatment in CIJ during the period 2005-2016. These users, between the ages of twelve and sixty-five, amounted to 263076 cases (approximately 20 to 22000 a year). An additional analysis focused on two specific years: 2005 and 2016 (19274 and 22897 cases respectively, grouped by sex and age range: $12-17,18-35$ and 36-65).

In view of the great similarity in patterns of use between men and women reported in population surveys, and in order to explore this in the treatment-seeking population, the second part includes a comparative analysis of the sample of 11595 cases treated in 2016, all of which had reported using marijuana in the previous thirty days. Respondents were classified by sex and age range (excluding users aged 36-65 years since the analysis of trends yielded fewer changes in marijuana use for this group).

The information was drawn from the CIJ's Sistema de Información Epidemiológica del Consumo de Drogas (SIECD) [Institutional System for Epidemiological Information on Drug Use], which gathers information on drug users through a census at 107 points across the country. The SIECD is one of the oldest systems in Mexico for gathering information on drug use (Medina-Mora, Cravioto, Ortíz, Kuri \& Villatoro, 2003). It is an institutional system with pre-established standardized indicators (Griffiths, Vingoe, 
Hunt, Mounteney \& Hartnoll, 2000), adjusted in 2004 to incorporate data reflecting observable national trends.

Despite constraints in terms of the generalization of results, the SIECD provides relevant data on substance use in a group affected by the problem (Díaz, Sánchez, \& Guisa, 2004; Global Assessment Program on Drug Abuse, European Monitoring Center for Drugs and Drug Addiction, 2006). This information made it possible to identify risk factors, emerging issues, treatment needs and trends that can influence the implementation of treatment centers and public policy and provide indicators for evaluating the impact of current programs (UN Drug Control Programme, 2003).

The system operates by registering new cases, including first-time treatment seekers, yet excluding repeat cases. For the purpose of monitoring cases, the system gathers sociodemographic information, demand indicators (determinants, reasons for consultation, prior measures taken and associated problems reported) and uses data for twenty six substances. The exploration of patterns of use includes: lifetime use, use in the past thirty days, age of onset of use, initiation drugs, length of time between onset of use and treatment seeking, highest impact drugs and frequency of abuse in the past thirty days.

This information is gathered through self-reporting at the first consultation, which includes a semi-structured interview conducted by physicians, psychiatrists, psychologists and members of the medical staff at CIJ, based on standardized instructions for applying these interviews and using them to compile individuals' electronic medical records. The information gathered for epidemiological follow up is based on consent, guaranteeing confidentiality and anonymity.

For this study, information was obtained on age, sex, lifetime use, use in the past thirty days before seeking treatment for use of marijuana, tobacco, alcohol, cocaine, inhalants, amphetamines, methamphetamines, ecstasy, benzodiazepines, hallucinogens and heroin; age at onset of use of illegal drugs and length of use; number of illegal drugs used during the respondent's lifetime or in the past month; number of times the respondent used drugs in the past thirty days. Data were also recorded on the drug of choice and the drug with the highest impact (the substance that led the user to seek treatment) as well as illegal initiation drugs.

In the first part, the analysis included an estimate, through $\chi^{2}$ (chi squared), of the differences in the proportions of marijuana used in the respondent's lifetime, in the past thirty days, and as the drug with the highest impact, recorded among the populations attended in 2005 and 2016, by age range and sex. The average actual growth rate of cannabis use between these two years was also estimated, using the formula: $(N / n)^{1 / 11}-1$, where $N$ are the cases received in treatment in 2016, $n$ those reported in 2005 and 11, the lapse of years of interest for this study. At first, the average annual growth rate of treatment seekers was estimated, followed by the average annual growth rate of marijuana users, which was then divided by the former.

In the second part, bivariate tests were used to determine the differences in patterns of use reported by women and men aged 12-17 and 18-35, current marijuana users who sought treatment in 2016. Analyses were conducted using the 19.0 version of the SPSS program.

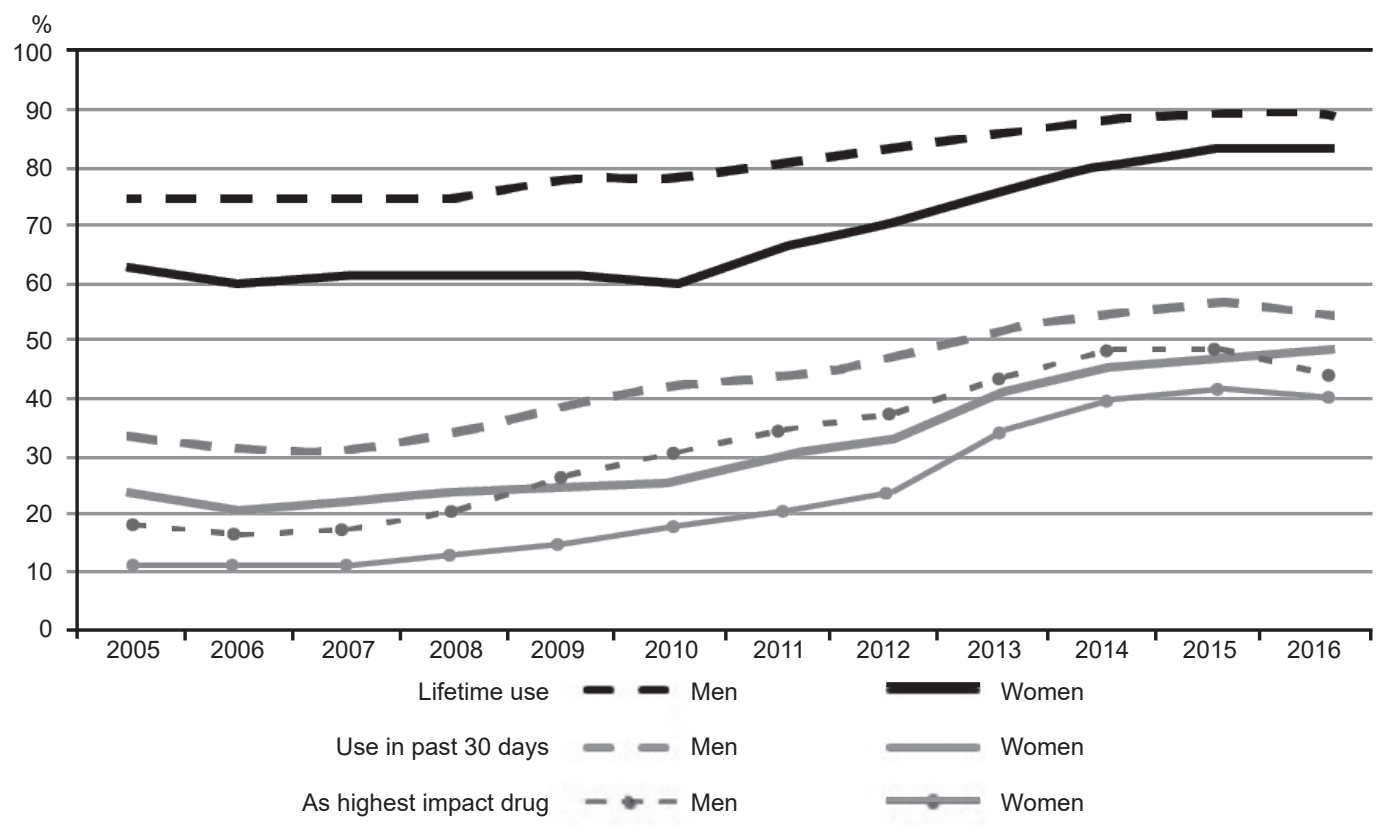

Figure 1. Trends in marijuana use by sex. Patients ages 12-65, first-time treatment seekers at ClJ, 2005-2016 (proportional differences between 2005 and 2016, significant to .000). 
Table 1

Trends in marijuana use by sex (\%). Patients ages 12-65, first-time treatment seekers at ClJ, 2005-2016

\begin{tabular}{|c|c|c|c|c|c|c|c|c|c|c|c|c|c|}
\hline Use & 2005 & 2006 & 2007 & 2008 & 2009 & 2010 & 2011 & 2012 & 2013 & 2014 & 2015 & 2016 & $\begin{array}{c}\text { Proportional } \\
\text { difference between } \\
2005 \& 2016\left(\chi^{2}\right)\end{array}$ \\
\hline Lifetime use & 72.3 & 72.0 & 71.5 & 71.7 & 74.6 & 73.9 & 77.7 & 80.5 & 84.4 & 86.9 & 88.1 & 87.5 & $1,523.45(1)^{*}$ \\
\hline Men & 74.2 & 74.3 & 73.7 & 74.2 & 77.7 & 77.3 & 80.4 & 82.9 & 86.3 & 88.4 & 89.2 & 88.4 & $1,166.70(1)^{*}$ \\
\hline Women & 62.2 & 59.8 & 60.3 & 60.0 & 60.5 & 58.8 & 65.3 & 69.9 & 75.9 & 80.4 & 83.1 & 83.5 & $418.09(1)^{*}$ \\
\hline In the past 30 days & 31.0 & 29.4 & 29.0 & 31.5 & 35.4 & 38.4 & 41.0 & 43.6 & 49.1 & 52.7 & 54.4 & 53.0 & $2,060.18(1)^{*}$ \\
\hline Men & 32.5 & 31.1 & 30.6 & 33.3 & 37.9 & 41.4 & 43.6 & 46.1 & 51.2 & 54.4 & 56.1 & 54.2 & $1,657.33(1)^{*}$ \\
\hline Women & 22.8 & 20.2 & 21.2 & 23.3 & 24.0 & 25.2 & 29.6 & 32.4 & 39.8 & 45.0 & 46.8 & 47.5 & $459.69(1)^{*}$ \\
\hline As highest impact drug & 16.3 & 14.8 & 15.2 & 18.6 & 23.6 & 27.4 & 31.5 & 34.2 & 41.8 & 45.9 & 46.6 & 43.6 & $3,473.74(1)^{*}$ \\
\hline Men & 17.5 & 15.6 & 16.2 & 19.9 & 25.6 & 29.6 & 34.0 & 36.7 & 43.6 & 47.4 & 48.0 & 44.3 & $2,764.95(1)^{*}$ \\
\hline Women & 9.8 & 10.4 & 10.3 & 12.4 & 14.1 & 17.2 & 20.0 & 22.8 & 33.9 & 39.3 & 40.8 & 40.3 & $772.46(1)^{*}$ \\
\hline
\end{tabular}

Note: ${ }^{*} p=.000$

\section{RESULTS}

\section{Trends in marijuana use for the population treated between 2005 and 2016}

As previously noted, the population aged twelve to sixty-five treated between 2005 and 2016 amounted to 263076 cases with an average age of $23.5(S D=10.1), 82.2 \%$ males and $17.8 \%$ females. The proportion of cannabis use registered during the period shows a clear upward trend in both lifetime use (LU) and use in the past month (PM). The increase is most striking after 2010. There is also an upward trend in marijuana as the drug with the highest impact (DHI), meaning that it is the drug that increasingly causes users to seek treatment (Figure 1, Table 1).

The comparison of the two sexes shows that increased use is more pronounced among women, for whom an average real annual growth rate (ARAGR) of $2.7 \%$ was established in the LU category and $6.9 \%$ in the PM category. Both these rates are higher than those observed among men, which are $1.6 \%$ and $4.8 \%$, respectively. The same occurs for the DHI category, where the increase for women is $13.7 \%$ as opposed to $8.8 \%$ for men (Table 2).

Age range analyses demonstrate significant increases in the groups 12 to 17 years (ARAGR $\mathrm{LU}=2.8 \%, \mathrm{PM}=5.3 \%$ and DHI $=8.8 \%$ ) and 18 to 35 years (ARAGR $\mathrm{LU}=1.4 \%$, $\mathrm{PM}=4.3 \%$ and $\mathrm{DHI}=7.7 \%$ ) although not in the group aged 36 to 65 years. In this latter group the rate was actually slightly negative (ARAGR LU $=-.1 \%, \mathrm{PM}-1.4 \%$ and $\mathrm{DHI}=-1.0 \%$ ) except for women in the LU category, where a slight increase was registered (Figures 2 and 3, Table 2).

The highest comparative increase is in the group aged 12 to 17 , although the greatest differences between the sexes were recorded in the increase of marijuana use in the group aged 18 to 35, in which women showed higher growth rates than men. Whereas in the LU category men showed 1.3\% ARAGR, the percentage of women was $2.2 \%$; for PM use, ARAGR was $4.1 \%$ for men and $6.6 \%$ for women. Finally, in the category citing marijuana as the drug with the highest impact, ARAGR was $7.3 \%$ for men and $13.2 \%$ for women (Table 2).

Table 2

Average real annual increase in marijuana use rates between 2005 and 2016, by age range and sex. . Patients ages 12-65 years old, first-time treatment seekers at ClJ

\begin{tabular}{|c|c|c|c|c|}
\hline \multirow[b]{2}{*}{ Marijuana use } & \multicolumn{4}{|c|}{ Age range } \\
\hline & 12 to 65 yrs. & 12 to 17 yrs. & 18 to 35 yrs. & 36 to 65 yrs. \\
\hline Lifetime use & $1.7 \%$ *** & $2.8 \%$ *** & $1.4 \% * * *$ & $-.1 \%$ \\
\hline Men & $1.6 \%$ *** & $2.8 \%$ *** & $1.3 \% * * *$ & $-.4 \% *$ \\
\hline Women & $2.7 \%$ *** & $3.0 \% * * *$ & $2.2 \% * * *$ & $1.6 \%$ * \\
\hline In the past 30 days & $5.0 \%$ *** & $5.3 \%$ *** & $4.3 \%$ *** & $-1.4 \%$ * \\
\hline Men & $4.8 \%$ *** & $5.2 \%$ *** & $4.1 \%$ *** & $-1.6 \%$ ** \\
\hline Women & $6.9 \% * * *$ & $5.9 \% * * *$ & $6.6 \% * * *$ & $-.4 \%$ \\
\hline As highest impact drug & $9.3 \%$ *** & $8.8 \%$ *** & $7.7 \%$ *** & $-1.0 \%$ \\
\hline Men & $8.8 \%$ *** & $8.2 \%$ *** & $7.3 \%$ *** & $-1.3 \%$ \\
\hline Women & $13.7 \%$ *** & $11.6 \%$ *** & $13.2 \%$ *** & $.8 \%$ \\
\hline
\end{tabular}

Note: ${ }^{a}$ Statistical significance of the difference in proportions recorded in 2005 and 2016, established by $\chi^{2}$ (chi squared).

${ }^{*} p=.05^{* *} p=.001^{* \star *} p=.000$ 


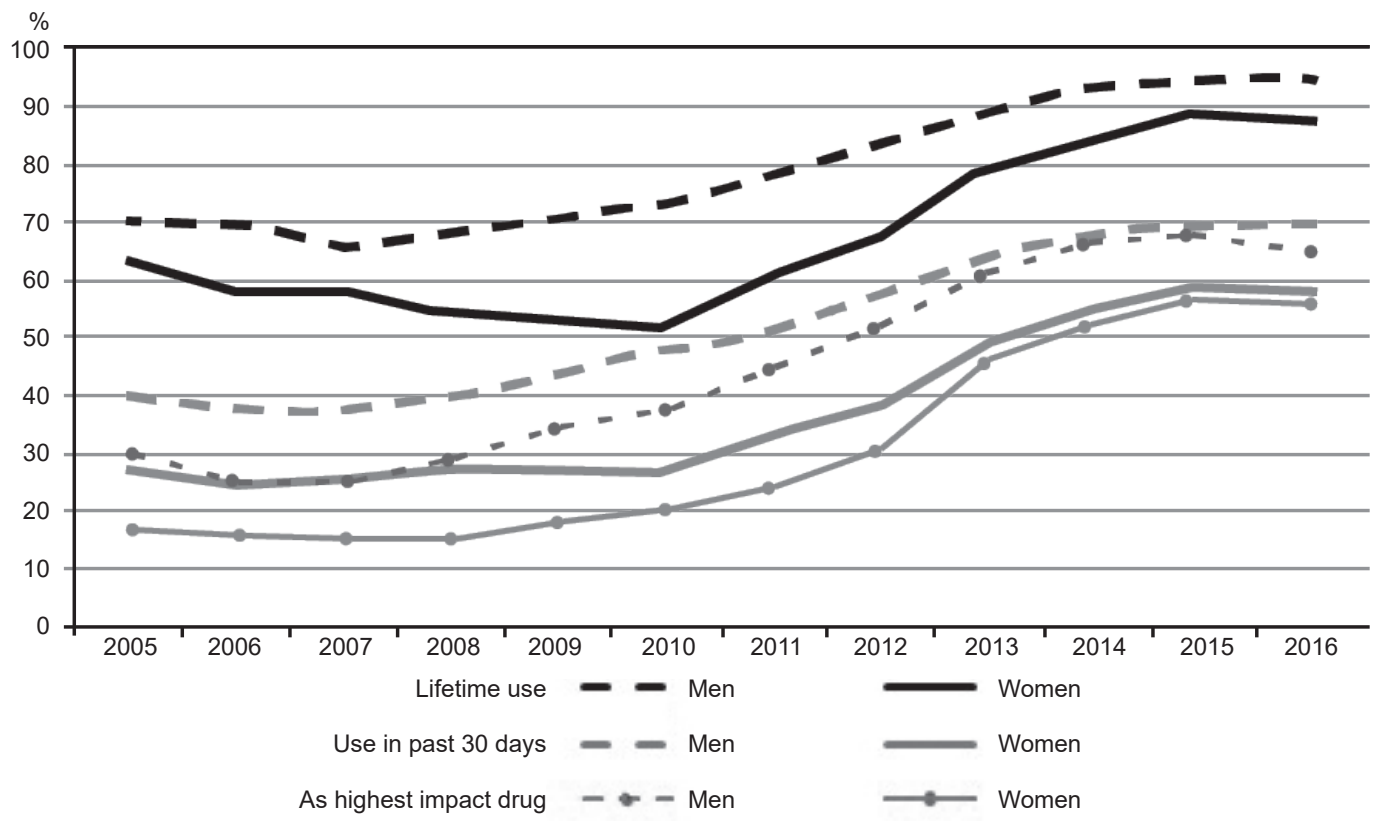

Figure 2. Trends in marijuana use by sex.Patients ages 12-17, first-time treatment seekers at CIJ, 2005-2016 (proportional differences between 2005 and 2016, significant to .000).

\section{Comparison between male and female marijuana users seeking treatment in 2016}

Users age 12 to 17

The sample of active cannabis users aged 12 to 17 included 7113 young adults, 5753 boys ( $80.9 \%$ of the sample) and 1360 girls (19.1\%), with an average age of 15.2 $(S D=1.4)$.
The average age of onset of use was $13.8(S D=1.5)$ for both boys and girls. Most users of both sexes report using cannabis as their first illegal drug $(92.4 \%$ and $90.4 \%$, respectively; $\chi^{2}=6.0, g l=1, p=.014$ ).

The period between initiating illegal drug use and seeking treatment at a CIJ was longer in boys $(\overline{\mathrm{X}}=1.5$ years, versus $\overline{\mathrm{X}}=1.2$ year; $t=7.233, g l=2259.6, p=.000$ ). Girls, on the other hand, reported a greater number of ille-

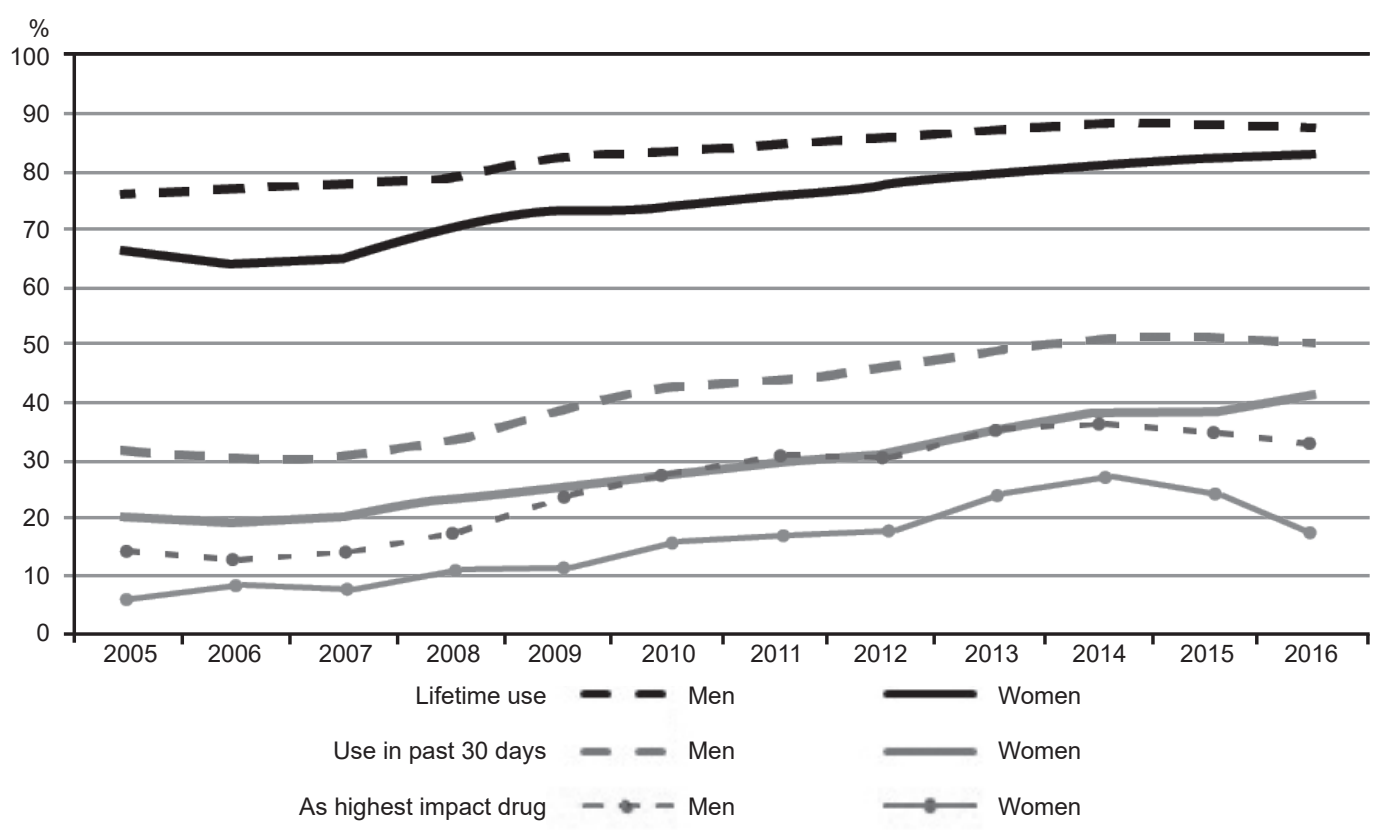

Figure 3. Trends in marijuana use by sex. Patients ages 18-35 years old, first-time treatment seekers at CIJ, 2005-2016 (proportional differences between 2005 and 2016, significant to .000). 
gal substances used both in LU categories $(\overline{\mathrm{X}}=1.95$ versus $\overline{\mathrm{X}}=1.86 ; t=2.348, g l=1972.106, p=.019)$ and $\mathrm{PM}(\overline{\mathrm{X}}=1.45$ versus $\overline{\mathrm{X}}=1.35 ; t=4.201, g l=1888.194, p=.000)$.

Marijuana is the drug of choice for both boys and girls (78.4\% of men, $72.4 \%$ of women; $\chi^{2}=22.72, g l=1, p=.000$ ), as well as the drug with the highest impact $(74.8 \%$ of men, $70.8 \%$ of women; $\chi^{2}=9.27, g l=1, p=.002$ ). It was observed that the proportion of boys was significantly higher than that of girls in both cases.

As for the use of other substances, girls reported significantly higher percentages than boys in both the LU and PM categories. Girls reported a higher LU of cocaine $(23.1 \%$ versus $\left.20.5 \% ; \chi^{2}=6.196, g l=1, p=.013\right)$ and benzodiazepines $\left(14.2 \%\right.$ versus $11.3 \%$; $\left.\chi^{2}=8.926, g l=1, p=.023\right)$, as well as for ecstasy and amphetamines.

With regards to PM use, girls reported a significantly higher use of methamphetamines $(10.0 \%$ versus $7.7 \%$; $\left.\chi^{2}=8.042, g l=1, p=.005\right)$, cocaine $(9.3 \%$ versus $7.1 \%$; $\left.\chi^{2}=7.347, g l=1, p=.007\right)$ and benzodiazepines $(6.4 \%$ versus $\left.4.0 \% ; \chi^{2}=14.355, g l=1, p=.000\right)$, as well as for hallucinogens, ecstasy and amphetamines.

Conversely, boys reported more frequent drug use in the past 30 days than women $(\overline{\mathrm{X}}=2.5$ versus $\overline{\mathrm{X}}=2.2 ; t=$ $6.698, g l=5888, p=.000$ ).

Users ages 18 to 35

The sample for LM marijuana users aged 18 to 35 included 4482 cases; 3,881 men (86.6\%) and 601 women $(13.4 \%)$, with an average age of $22.6(S D=4.6)$. Unlike the group aged 12-17, in which boys and girls reported the same age of onset of illegal substance use, the men in this age group reported drug use onset at 14.5 (versus 16.3 for women; $t=5.66, g l=729.488, p=.000)$, and marijuana use initiation at 15.9 years $(S D=3.0)$ while women did so at 16.9 years on average $(S D=3.7)$, which is a significant difference $(t=6.381, g l=725.572, p=.000)$. More than $80 \%$ of drug users of both sexes began using illegal substance with marijuana.

In contrast to the younger age group, the number of illegal drugs used LU was the same for both sexes $(\bar{X}=2.89$ for men and $\bar{X}=2.93$ for women). For PM use, there is a slightly higher number for women (1.79 versus 1.69 for men; $t=2.328, g l=748.474, p=.020)$. Marijuana is the drug of choice for both sexes, although the proportion of men that reported this is significantly higher than that of women $\left(66.4 \%\right.$ versus $\left.55.7 \% ; \chi^{2}=26.31, g l=1, p=.000\right)$. Marijuana was also the drug with the highest impact, with 5.2 percentage points of difference between the two sexes (52.7\% men, $47.5 \%$ women; $\left.\chi^{2}=5.71, g l=1, p=.017\right)$.

With regard to other substances consumed, a larger percentage of women reported LM use of ecstasy $(20.1 \%$ versus $\left.13.0 \%, \chi^{2}=21.774, g l=1, p=.000\right)$ and hallucinogens (5.8\% versus $\left.3.0 \% ; \chi^{2}=12.845, g l=1, p=.000\right)$.

Finally, like the boys in the 12-17 age group, the men in this group reported more frequent drug use in the past 30 days than women $(\overline{\mathrm{X}}=4.17$ versus $\overline{\mathrm{X}}=4.97$ of women; $t=3.587, g l=654.411, p=.000)$.

\section{DISCUSSION AND CONCLUSION}

A number of conclusions can be drawn from the above results. Firstly, marijuana is the main drug used by illegal drug users seeking treatment and the population at large, as reported in a variety of national and international surveys (SSA, CONADIC, INPRFM, INSP, 2011; Villatoro, Oliva, Mujica, Fregoso, Bustos \& Medina-Mora, 2015; United Nations Office on Drugs and Crime, 2016). Marijuana use has also experienced an upward trend, as reported by Mexican national surveys, particularly since 2010 , which translates into a proportionally larger demand for marijuana use treatment (Gutiérrez, 2016).

The growth rates reported for the various age groups studied show that the youngest patients, particularly those under eighteen, have made the greatest contribution to the general increase in marijuana use. Furthermore, an analysis of the data by sex shows that females, both girls under 18 and young adult women, have contributed the most to the increased use of marijuana, according to school and census surveys (SSA, CONADIC, INPRFM, INSP, 2011; INPRFM, CONADIC, SSA, 2015).

It is also striking that, whereas the youngest female users have shown the largest increase in LU, which is primarily related to experimental use, women between 18 and 35 have the highest growth rate for PM use, which is a better indicator of regular use.

At the same time, growth rates for marijuana use showed smaller differences between boys and girls in the 12-17 age group, which may be a reflection of the growing similarity in patterns of use between those of young men and women, as borne out by student surveys (Villatoro, Oliva, Mujica, Fregoso, Bustos \& Medina-Mora, 2015).

Similarly, female marijuana users, mainly those under 18 , report using a wider range of illegal substances than men. In contrast with the findings of studies until recently (Gutiérrez, 2016), none of the substances considered registered higher proportions of male than female users. However, frequency of use in the past 30 days continues to be higher among men.

In short, the increase in marijuana use in recent years has particularly affected the under-18 population, particularly girls, who are tending to adopt more complex patterns of use. This emphasizes the need for a more in-depth study of the factors and conditions that may be involved.

The limitations of the information gathered on treatment seekers include the fact that it cannot be generalized and is restricted to pre-established clinical indicators. Nevertheless, this study coincides with the observable changes and 
trends in marijuana use across different population groups and through different means, and contributes to increasing knowledge about these factors as a central component in treatment demand.

\section{Funding}

This study is derived from the Sistema de Información Epidemiológica del Consumo de Drogas of the Centros de Integración Juvenil and did not receive any specific financing.

\section{Conflicts of interest}

The authors have no conflicts of interest.

\section{Acknowledgements}

The authors wish to thank Jessica Zapata Téllez and Cristina Cruz Cortés for their support in retrieving information for this study.

\section{REFERENCES}

Castillo, P. I., \& Gutiérrez, A. D. (2008). Consumo de drogas en mujeres asistentes a centros de tratamiento especializado en la Ciudad de México. Salud Mental, 31(5), 351-359.

Díaz Negrete, D., Sánchez Huesca, R., \& Guisa Cruz, V. (2003). Registro y estudio de casos en centros de tratamiento especializado. Metodología para la elaboración de estudios epidemiológicos a nivel nacional y local y estudios para grupos especiales relacionados con las adicciones (pp. 73-77). México: Consejo Nacional contra las Adicciones.

Griffiths, P., Vingoe, L., Hunt, N., Mounteney, J., \& Hartnoll, R. (2000). Drug information systems, early warning, and new drug trends: Can drug monitoring systems become more sensitive to emerging trends in drug consumption? Substance Use \& Misuse, 35(6-8), 811-844.

Gutiérrez, A. D. (2016). Consumo de sustancias en pacientes de primer ingreso a tratamiento. Primer semestre del 2016. Usuarios de drogas ilegales. (Informe de investigación 16-09a). México: Centros de Integración Juvenil. Retrieved from http://www.cij.gob.mx/programas/Investigacion/investigacion.html
Instituto Nacional de Psiquiatría Ramón de la Fuente Muñiz, Comisión Nacional Contra las Adicciones, Secretaría de Salud (2015). Encuesta Nacional de Consumo de Drogas en Estudiantes 2014: Reporte de Drogas. México: INPRFM.

Kuri, P., Álvarez, C., Cravioto, P., García, E., Galván, F., \& Tapia, R. (2002). Sistema Epidemiológico y Estadístico de las Defunciones (SEED)., Observatorio mexicano en tabaco, alcohol y otras drogas, 2002 (pp. 111-124). México: Secretaría de Salud.

Linares, N., Cravioto, P., García, G., \& Medina-Mora, M. E. (2002). Porcentaje de continuidad del consumo de la mariguana en México: Una aproximación desde las encuestas nacionales de adicciones. Salud Mental, 25(2), 1-8.

Medina-Mora, M. E., Cravioto, P., Ortíz, A., Kuri, P., \& Villatoro, J. (2003). Mexico: Systems for the epidemiological diagnosis of drug abuse. Bulletin on Narcotics, 55(1-2), 105-119.

Ortiz, A., Soriano, A., Meza, D., Martínez, R., \& Galván, J. (2006) Uso de sustancias entre hombres y mujeres, semejanzas y diferencias. Resultados del sistema de reporte de información en drogas. Salud Mental, 29(5), 32-37.

Programa de las Naciones Unidas para la Fiscalización Internacional de Drogas (2003). Elaboración de un sistema integrado de información sobre las drogas. Austria: Oficina de las Naciones Unidas contra la Droga y el Delito.

Programa Mundial de Evaluación del Uso Indebido de Drogas, Observatorio Europeo de las Drogas y las Toxicomanías (2006). Orientaciones para la medición de la demanda de tratamiento de drogas. Austria: Oficina de las Naciones Unidas contra la Droga y el Delito.

Secretaria de Salud, Consejo Nacional contra las Adicciones, Instituto Nacional de Psiquiatría Ramón de la Fuente Muñiz, Instituto Nacional de Salud Pública (2011). Encuesta Nacional de Adicciones 2011, México: Instituto Nacional de Salud Pública. Retrieved from: www.conadic.salud.gob.mx

United Nations Office on Drugs and Crime (2016). World Drug Report. Austria: UNODC.

Villatoro, J., Oliva, N., Mujica, R., Fregoso, D., Bustos, M., \& Medina-Mora, M. E. (2015). Panorama actual del consumo de sustancias en estudiantes de la Ciudad de México. México: Instituto Nacional de Psiquiatría Ramón de la Fuente Muñiz, Administración Federal de Servicios Educativos en el Distrito Federal, Instituto para la Atención y Prevención de las Adicciones. Retrieved from www. uade.inpsiquiatria.edu.mx 